\title{
Pemanfaatan Minyak Serai Sebagai Bahan Aktif Nanovirusida untuk Pengendalian Penyakit Kuning pada Cabai
}

\author{
Dwiwiyati Nurul Septariani*, Hadiwiyono, Puji Harsono, dan Munti'ah Mawar \\ Program Studi Agroteknologi, Fakultas Pertanian, Universitas Sebelas Maret \\ *Correspoding Author : nurulseptariani@gmail.com
}

\begin{abstract}
ABSTRAK
Cabai merupakan komoditas yang penting secara ekonomi bagi Kelompok Tani Sidoluhur dan Kelompok Wanita Tani Puteri Petani Mandiri di Desa Cabeyan, Kecamatan Bendosari, Kabupaten Sukoharjo. Minimnya pengetahuan petani tentang pengendalian OPT menyebabkan pertanaman cabai terkendala berbagai penyakit terutama virus kuning yang dapat menurunkan hasil hingga 100\%. Akhir-akhir ini berkembang formulasi nanoteknologi yang dapat meningkatkan efektivitas pestisida nabati. Nanoteknologi pestisida adalah formulasi partikel nanopestisida yang meningkatkan kelarutan, tingkat disolusi, dan dispersi saat aplikasi sehingga meningkatkan efikasi pestisida. Salah satu jenisnya yaitu nanovirusida yang berfungsi menekan infeksi virus pada tanaman. Kegiatan pengabdian ini bertujuan memperkenalkan nanovirusida nabati untuk mengatasi masalah penyakit pada pertanaman cabai. Metode kegiatan berupa penyuluhan mengenai cara mengendalikan berbagai organisme pengganggu tanaman (OPT) pada cabai, pembuatan demplot pembibitan, serta pelatihan teknis budidaya cabai dengan nanovirusida nabati. Aplikasi nanovirusida di lahan cabai lokasi mitra terbukti efektif menurunkan intensitas penyakit kuning lebih dari 50\% dibandingkan tanpa pengendalian. Hasil kegiatan yang diperoleh berupa peningkatan keterampilan petani pada pengendalian virus kuning dan serangga penularnya dengan nanovirusida.
\end{abstract}

Kata kunci: Cymbopogon nardus; minyak serai wangi; aphid; Pepper yellow leaf curl virus; tular serangga

\section{ABSTRACT}

Chilli is an economically important commodity to farmers Sidoluhur dan farm women group Puteri Petani Mandiri in Cabeyan Village, Bendosari Sub-district, Sukoharjo Regency. However farmers are constrained yellow leaf curl disease that reduce yields until 100\%. Recently researchers has found the nanotechnology formulations increased biopesticide effectiveness. Pesticide nanotechnology is nanoparticle-based pesticide formulation increased solubility, dissolution rate, dispersion during application thereby increasing the efficacy of pesticides. This activity intended to introducing biopesticide nanotechnology to solve problem of diseases in chili. The methods are counseling on how to identify and control various pests and diseases in chili, plot demonstration of chili nursery, and cultivation technical training of chili by biopesticide nanotechnology. Application of nanoviruside in chili plantation proven effectively reducing yellow disease intensity more than $50 \%$ than non application. The result of this activity obtained are knowledge and skills improvement of controlling yellow disease on chili and insect vector by nanoviruside application.

Keywords: Cymbopogon nardus; citronella oil; aphid; Pepper yellow leaf curl virus; insecttransmitted

\section{PENDAHULUAN}

Serangan virus kuning pada akhir-akhir ini terus meningkat di lapangan, seperti yang disampaikan Menteri Pertanian Indonesia bahwa masalah yang banyak dihadapi petani cabai akhir-akhir ini adalah penyakit kuning (pepper yellow leaf curl virus, PYLRV) atau virus Gemini (Budi 2018). Demikian pula masalah yang dialami petani cabai di lokasi mitra yaitu Desa Cabeyan, Kecamatan Bendosari, Kabupaten Sukoharjo. Beberapa petani bahkan 
beralih ke tanaman lain karena mengalami kerugian besar akibat gagal panen. Di lapangan virus kuning dapat menurunkan hasil cabai 20$100 \%$ (Setiawati et al. 2008), cabai yang yang terserang $100 \%$ tidak dapat menghasilkan (Ely Novrianty et al. 2013), karena menurunkan produk fisologi tanaman (Ariyanti 2012). Virus ini memiliki inang yang luas dan tidak terbatas pada Solanaceae tetapi juga tanaman dari famili lain seperti mentimun, kacang buncis, kacang panjang, dan babadotan (Gaswanto et al. 2016). Virus ini tular serangga seperti Thrips sp., Bemisia sp, dan Myzus sp. (Vivaldy et al. 2017). Oleh karena itu, pengembangan pengendaliannya tidak saja ditujukan pada virusnya, tetapi juga penting ditujukkan serangga vektornya. Gunaeni dan Wulandari (2010) melaporkan bahwa efektivitas pengendalian serangga vektor efektif menurunkan serangan virus kuning.

Penggunaan pestisida kimia masih menjadi pengendalian yang sangat diminati oleh petani cabai di lokasi mitra karena dirasakan praktis dan paling mudah dipahami. Namun demikian, lebih dari $90 \%$ pestisida mengalir ke lingkungan dan terbawa produk pertanian akibat aplikasi formulasi pestisida konvensional yang sangat merugikan. Beberapa tahun terakhir, nanoteknologi formulasi baru telah menunjukkan potensi besar dalam meningkatkan kemanjuran dan keamanan pestisida (Zhao et al. 2018). Berdasarkan permasalahan tersebut, tim pengabdian berinisiatif memperkenalkan pestisida alami ramah lingkungan dengan teknologi nano yang mudah digunakan dan lebih efektif menurunkan intensitas penyakit kuning pada cabai. Kegiatan pengabdian ini diharapkan mampu menyampaikan transfer pengetahuan untuk menyelesaikan permasalahan petani mitra, mulai dari teknik budidaya yang tepat sehingga mendukung kondisi pertumbuhan tanaman optimal dengan menggunakan teknologi nano namun menggunakan bahan-bahan alami ramah lingkungan demi mendukung pertanian berkelanjutan.

Kondisi lahan yang kering di lokasi petani mitra juga menjadi permasalahan tersendiri dalam budidaya tanaman cabai. Pengairan berasal dari pompa sumur yang hanya dapat digunakan secara bergantian oleh para petani. Kebutuhan air yang tidak tercukupi dapat menyebabkan tanaman rentan terhadap hama dan penyakit. Aplikasi pestisida pun menjadi kurang efektif akibat tingkat kelarutan rendah pada lahan kering. Nanoteknologi biopestisida mampu larut dan terserap secara merata pada tanaman sehingga efektif menurunkan intensitas penyakit.

Menurut Shah et al. (2016), formulasi pestisida dengan bahan aktif sebagai partikel nano memungkinkan peningkatan yang signifikan dalam kelarutan air, laju disolusi, dan keseragaman dispersi pada aplikasi tanpa perubahan molekul kimia bahan aktif insektisida yang dibuat. Pengembangan formulasi pestisida berbasis nanoteknologi bertujuan untuk melepaskan bahan-bahan aktif dalam jumlah yang diperlukan dan cukup dalam merespon pemicu lingkungan dan tuntutan biologi melalui mekanisme pelepasan terkontrol. Oleh karena itu, Manjunatha et al. (2016) menyampaikan bahwa nanoteknologi berpotensi tinggi mendukung sistem pertanian berkelanjutan, sedangkan Duhan et al. (2017) menyatakan bahwa nanoteknologi merupakan perspektif baru pertanian yang tepat. Menurut Worrall et al. (2018) nanoteknologi dapat menawarkan keuntungan bagi pestisida seperti meningkatkan toksisitas, meningkatkan umur simpan, dan meningkatkan kelarutan dalam air pestisida yang sulit larut. Ariningsih (2016) mengatakan bahwa berdasarkan kajiannya nanoteknologi mempunyai prospek yang cerah untuk diterapkan pada bidang pertanian di Indonesia. Penerapan nanoteknologi pestisida nabati dapat mengurangi penggunaan pestisida kimia sintetik sehingga dapat mengurangi dampak negatif pada lingkungan karena aplikasi pestisida.

Penerapan biopestisida berteknologi nano pada lahan petani mitra diharapkan dapat menyelesaikan masalah keparahan penyakit kuning dan kondisi lahan kering secara aman bagi para petani, tanaman, maupun lingkungan. Kegiatan pengabdian ini bertujuan memperkenalkan nanoteknologi pestisida nabati untuk menyelesaikan masalah penyakit pada pertanaman cabai di Kelompok Tani Sidoluhur dan Kelompok Wanita Tani Puteri Petani Mandiri di Desa Cabeyan Kecamatan Bendosari, Kabupaten Sukoharjo.

\section{METODE}

Berdasarkan permasalahan, tantangan dan kebutuhan yang diperlukan Mitra dalam Program Kemitraan Masyarakat, maka Tim Pengabdi dari Universitas Sebelas Maret memformulasikan strategi dan taktik khusus yakni solusi yang ditawarkan untuk mencapai tujuan memperkenalkan nanoteknologi 
pestisida nabati untuk pengendalian virus kuning dan serangga penularnya pada budidaya cabai di Desa Cabeyan. Metode yang diterapkan untuk merealisasikan Program Kemitraan Masyarakat (PKM PNBP UNS) untuk Mitra Kelompok Tani Sidoluhur dan Kelompok Wanita Tani Puteri Petani Mandiri Desa Cabeyan, Kecamatan Bendosari, Kabupaten Sukoharjo berupa:

\section{Penyuluhan}

Metode penyuluhan yaitu ceramah dengan menggunakan media cetak (hand out), elektronik (power point), dan alat peraga. Ceramah dilanjutkan dengan diskusi dan tanya jawab dengan para peserta untuk membantu memberi solusi atas kendala-kendala yang terjadi pada budidaya cabai di daerah mitra. Kegiatan penyuluhan juga diselingi praktek pembuatan ekstrak minyak serai wangi secara sederhana yang selanjutnya digunakan dalam praktek pengendalian virus kuning di lapangan. Proses pembuatan ekstrak minyak serai $0,6 \%$ dilakukan dengan menghaluskan serai yang telah dibersihkan sebanyak $1 \mathrm{~kg}$, kemudian dilarutkan dalam air $250 \mathrm{ml}$ dan didiamkan semalam. Ekstrak serai disaring dan dilarutkan dalam akuades dengan konsentrasi 0,6\%.

\section{Demontrasi plot cabai}

Tim Pengusul memfasilitasi pembuatan demplot dimulai dengan pembibitan cabai merah. Benih cabai verietas Hot Beauty ditanam pada pot tray dengan menggunakan media campuran tanah dan pupuk kandang. Bibit cabai dipindah tanam ketika sudah memiliki dua pasang daun sejati (21 hari setelah semai). Persiapan lahan diawali pembuatan bedengan yang ditutup mulsa hitam perak lalu dilubangi dan ditanami bibit cabai merah. Demplot menggunakan Rancangan Acak Kelompok Lengkap (RAKL). Petani mitra rutin mengamati lahan demplot termasuk melakukan perempelan tunas samping dan penalian batang tanaman cabai pada ajir.

\section{Pelatihan dan pendampingan transfer pengetahuan dan keterampilan pengendalian virus kuning pada usahatani cabai dengan nanovirusida \\ Pelatihan melibatkan 15 anggota}

Kelompok tani dan 10 anggota Kelompok wanita tani. Pelatihan berupa pendampingan secara langsung di lapangan mengenai budidaya tanaman cabai yang baik. Seluruh tahapan budidaya dilakukan mulai dari penyemaian, pemupukan, penanaman, pengairan, serta pengendalian hama penyakit di lapangan. Praktek pengendalian hama penyakit difokuskan pada tujuan kegiatan pengabdian yaitu aplikasi nanopestisida serai wangi untuk mengendalikan virus kuning pada cabai.

Aplikasi nanopestisida terdiri dari satu faktor yaitu macam-macam pestisida dengan faktor pestisida sintetik konsentrasi $0,1 \%$ (P1), nanopestisida konsentrasi 0,2\% (P2), ekstrak minyak serai $0,6 \%(\mathrm{P} 3)$, dan kontrol atau tanpa penggunaan pestisida (P0). Setiap perlakuan diulang sebanyak 15 kali. Jumlah unit yaitu 60 satuan percobaan. Jarak tanam cabai yang digunakan $75 \times 60 \mathrm{~cm}$, dalam satu bedeng tanam terdapat dua baris tanaman.

Pelatihan aplikasi nanopestisida pada daun cabai dilakukan pada taraf yang telah ditentukan. Pestisida, nanopestisida, dan ekstrak minyak serai wangi dipindahkan ke dalam sprayer kemudian disemprotkan pada permukaan cabai bagian bawah dengan tujuan agar lebih efektif karena serangga vektor terdapat pada bagian bawah daun. Perlakuan kontrol dilakukan dengan menggunakan air tanpa tambahan ekstrak maupun pestisida yang lain. Aplikasi penyemprotan dilakukan sebanyak 12 kali selama satu musim tanam, dimulai pada saat tanaman berumur 21 hari setelah tanam dengan interval penyemprotan 1 minggu sekali.

\section{Monitoring dan evaluasi}

Evaluasi kegiatan dilakukan dengan pengamatan pertumbuhan tanaman cabai dari setiap lahan petani mitra secara berkala. Pengamatan dilakukan pada beberapa aspek yaitu populasi serangga penular, intensitas penyakit kuning, pertumbuhan tanaman cabai, dan hasil panen buah cabai. Pengamatan pertama populasi tanaman yang terserang hama aphid setelah tanaman berumur 2 minggu setelah tanam (MST) dan pengamatan selanjutnya dilakukan satu minggu sekali sampai tanaman berproduksi (panen pertama). Analisis data dilakukan dengan analisis keragaman (Anova) menggunakan uji F 5\% dan 1\%. Untuk mengetahui perbedaan respon tiap perlakuan dilakukan uji lanjut Beda Nyata Terkecil 5\% pada tiap perlakuan.

\section{HASIL DAN PEMBAHASAN}

\section{Penyuluhan nanovirusida}

Kegiatan penyuluhan dilaksanakan di rumah salah satu anggota kelompok tani mitra di 
Desa Cabeyan, Kecamatan Bendosari, Kabupaten Sukoharjo (Gambar 1). Para petani mendengarkan seluruh materi yang berisi teknik budidaya tanaman cabai yang baik, berbagai jenis organisme pengganggu tanaman (OPT) pada tanaman cabai, dan teknik pengendaliannya yang ramah lingkungan. Peserta juga aktif mengikuti diskusi mengenai gangguan hama dan penyakit yang menyerang lahan pertanaman cabai miliknya. Metode pengendalian OPT terutama ditekankan dengan penggunaan bahanbahan alami yang mudah diperoleh di sekitar tempat tinggal petani mitra.

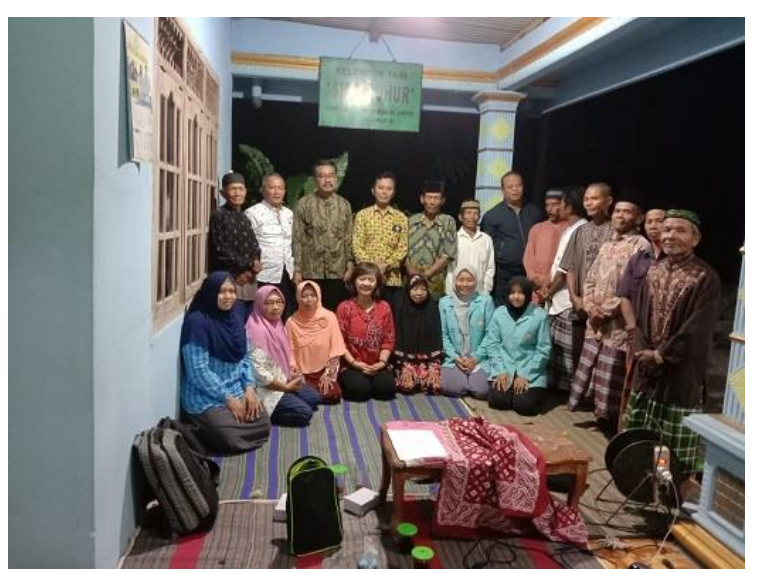

Gambar 1. Kegiatan penyuluhan aplikasi biopestisida serai wangi

Materi pengendalian OPT juga berisi proses pembuatan beberapa tanaman yang dapat digunakan sebagai biopestisida alami, salah satunya tanaman serai wangi. Pembuatan ekstrak tanaman yang mudah dilakukan membuat para petani lebih antusias dan bersemangat untuk mempraktekan sendiri serta segera beralih dari penggunaan pestisida kimia. Hasil yang lebih optimal dapat diperoleh dengan mengkombinasikan nanopestisida serai wangi dengan isolat jamur Trichoderma sp. Banyak penelitian telah membuktikan efektivitas Trichoderma sp. dalam menekan pertumbuhan jamur pathogen sehingga dapat bersinergi dengan biopestisida untuk mengendalikan pathogen secara lebih optimal.

\section{Demonstration plot}

Pembuatan demplot pembibitan cabai untuk kelompok wanita tani (KWT) menggunakan potray tanam yang praktis dan dapat digunakan berulang kali sehingga setelah PKM selesai KWT Puteri Petani Mandiri mempunyai usaha pembibitan sebagai income generating kelompoknya. Peserta berlatih melakukan pembibitan yang baik sehingga menghasilkan bibit cabai yang unggul dengan produktivitas tinggi dan tahan terhadap hama penyakit. Demplot pertanaman cabai di lahan juga diberikan kepada KT Sidoluhur sebagai sarana berlatih penerapan teknologi nano biopestisida dalam meningkatkan hasil panen (Gambar 2).

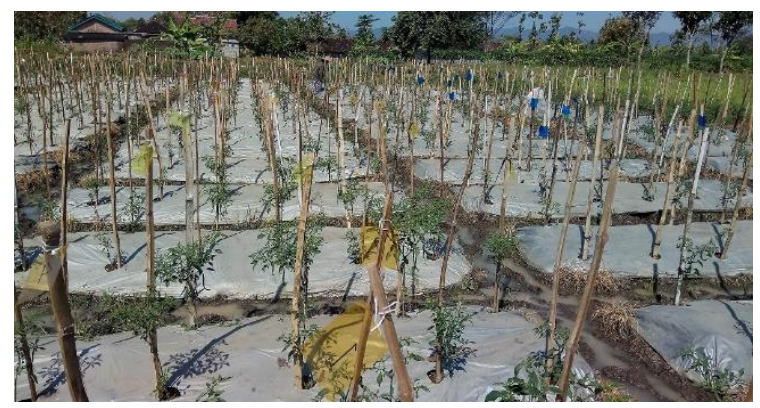

Gambar 2. Demplot aplikasi biopestisida serai wangi di lahan pertanaman cabai

Perawatan lahan demplot rutin dilakukan dengan mengamati gangguan hama penyakit yang terdapat pada lahan cabai sesuai kondisi lingkungan di lokasi mitra. Oleh karena itu, peserta memanfaatkan bahan alami yang terdapat di lingkungan sekitar untuk mengendalikan hama penyakit. Bahan pestisida alami lebih mudah diperoleh serta aman bagi kesehatan petani mitra dan lingkungan. Berdasarkan masalah penyakit kuning yang terdapat di lokasi mitra, Tim Pengabdian merekomendasikan penggunaan ekstrak serai wangi yang terbukti ampuh mengendalikan penyakit kuning.

Minyak serai wangi mengandung senyawa aktif yang dapat digunakan sebagai bahan baku pestisida nabati untuk mengendalikan hama dan penyakit tanaman. Hal ini berkaitan dengan sifatnya yang mampu membunuh, mengusir, dan menghambat aktivitas makan hama, serta mengendalikan penyakit tanaman yang bersifat antijamur, antibateri, antivirus, dan antinematoda. Aktifitas dari minyak serai wangi terhadap serangga adalah sebagai penolak (repellent) (Goodyer et al 2010, Kwon et al 2010), menarik (attractant), racun kontak, racun pernafasan, mengurangi nafsu makan, menghambat peletakan telur, menghambat pertumbuhan, menurunkan fertilitas, dan sebagai anti serangga vektor (Isman 2000). Sitronellal yang terkandung dalam minyak serai wangi bekerja dengan cara menghambat enzim asetilkolinesterase sehingga terjadi fosforilasi asam amino serin pada pusat 
asteratik enzim tersebut. Gejala keracunan pada serangga timbul karena adanya penimbunan asetilkolin yang menyebabkan gangguan system saraf pusat, kejang, kelumpuhan pernafasan, dan kematian (Mutchler 1991).

Serai wangi memiliki aktivitas biologi yang berspektrum luas, tidak toksik, sistemik, kompatibel dengan teknik pengendalian lain (seperti agens hayati), mudah terurai dan lebih ramah lingkungan. Selain itu, serai wangi juga bersifat tidak persisten karena mudah terurai secara alami sehingga tidak tahan lama dalam air, udara, di dalam tanah dan tubuh manusia (Hartati 2012). Oleh karena itu serai wangi mempunyai peluang yang sangat besar untuk dikembangkan menjadi produk biopestisida.

\section{Pelatihan dan pendampingan aplikasi nano biopestisida}

Pelatihan dilakukan untuk meningkatkan keterampilan Mitra terkait, tidak hanya keterampilan teknis budidaya cabai dengan teknologi nano biopestisida tetapi juga keterampilan berpikir dalam identifikasi virus kuning pada cabai sehingga peserta mampu memecahkan masalah, membuat keputusan, berpikir kritis dan berpikir kreatif untuk meningkatkan hasil cabai dengan biaya usahatani lebih murah dan harga jual yang tinggi (Gambar 3). Pendampingan dilakukan melalui pengamatan pada hasil pelatihan aplikasi penyemprotan nano biopestisida di lahan cabai petani mitra. Pengamatan menunjukkan pengendalian aphid dengan nanopestisida berhasil menurunkan kehilangan hasil cabai merah hingga 79\% (dibandingkan tanpa pengendalian) pada daerah endemis aphid dan penyakit virus kuning (Tabel 1). Penurunan kehilangan hasil juga lebih tinggi (44\%) dibandingkan aplikasi pestisida kimia profenofos. Pertanaman cabai merah yang diberikan aplikasi dengan minyak serai baik dengan teknologi formulasi nano maupun tanpa formulasi nano memberikan hasil yang lebih tinggi dibandingkan dengan pertanaman kontrol.

Tabel 1. Efektivitas aplikasi nanovirusida minyak serai terhadap rata-rata kehilangan hasil, jumlah buah cabai per tanaman, populasi aphid per tanaman cabai merah, dan intensitas penyakit virus kuning pada 103 hari setelah tanam

\begin{tabular}{llcccc}
\hline & \multicolumn{1}{c}{ Pengendalian } & $\begin{array}{c}\text { Kehilangan } \\
\text { hasil }\end{array}$ & $\begin{array}{c}\text { Jumlah } \\
\text { buah cabai }\end{array}$ & $\begin{array}{c}\text { Populasi } \\
\text { aphid }\end{array}$ & $\begin{array}{c}\text { Intensitas virus } \\
\text { kuning }\end{array}$ \\
\hline P0 & Tanpa Pengendalian & $23,96 \mathrm{~d}$ & $186,31 \mathrm{~d}$ & $8,32 \mathrm{c}$ & $28,27 \mathrm{c}$ \\
\hline P1 & Profenofos 0,1\% & $9,24 \mathrm{c}$ & $271,19 \mathrm{c}$ & $4,94 \mathrm{a}$ & $15,07 \mathrm{~b}$ \\
P2 & Nanopestisida M. Serai 0,2\% & $5,13 \mathrm{~b}$ & $318,84 \mathrm{~b}$ & $5,24 \mathrm{~b}$ & $13,53 \mathrm{ab}$ \\
P3 & Minyak Serai 0,6\% & $0,03 \mathrm{a}$ & $402,65 \mathrm{a}$ & $5,60 \mathrm{~b}$ & $11,87 \mathrm{a}$ \\
\hline
\end{tabular}

Keterangan: Angka yang diikuti huruf yang sama berbeda nyata pada taraf 5\%

Penurunan kehilangan hasil cabai petani mitra seiring dengan hasil pengamatan peubah pertumbuhan cabai merah. Petumbuhan pertanaman cabai merah yang mendapatkan perlakuan pestisida minyak serai secara umum menunjukkan kecenderungan penampilan yang lebih baik pada semua peubah seperti tinggi tanaman, jumlah cabang, jumlah daun, dan berat batang (Tabel 2). Hasil pengamatan mingguan terhadap populasi aphid secara periodik menunjukkan adanya kecenderungan populasi aphid pada pertanaman yang diaplikasi dengan minyak serai lebih rendah dibandingkan dengan pertanaman kontrol (Tabel 1).

Tabel 2. Pengaruh pengendalian aphid dengan nanopestisida terhadap rata-rata pertumbuhan cabai merah pada 112 hari setelah tanam

\begin{tabular}{|c|c|c|c|c|c|}
\hline \multicolumn{2}{|r|}{ Pengendalian } & \multirow{2}{*}{$\begin{array}{c}\text { Tinggi }(\mathrm{cm}) \\
20,23 \mathrm{a}\end{array}$} & \multirow{2}{*}{$\begin{array}{r}\text { Cabang } \\
43,77 a \\
\end{array}$} & \multirow{2}{*}{$\begin{array}{c}\begin{array}{c}\text { Jumlah } \\
\text { Daun }\end{array} \\
78,50 \mathrm{a}\end{array}$} & \multirow{2}{*}{$\begin{array}{c}\text { Berat Batang } \\
(\mathrm{g})\end{array}$} \\
\hline P0 & Tanpa Pengendalian & & & & \\
\hline $\mathrm{P} 1$ & Profenofos $0,1 \%$ & $28,29 b$ & $45,00 \mathrm{a}$ & $87,50 \mathrm{~b}$ & $28,57 \mathrm{~b}$ \\
\hline $\mathrm{P} 2$ & Nanopestisida M. Serai $0,2 \%$ & $30,36 b$ & $53,17 \mathrm{~b}$ & $97,50 \mathrm{c}$ & $48,06 \mathrm{c}$ \\
\hline P3 & Minyak Serai $0,6 \%$ & $43,39 c$ & $71,50 \mathrm{c}$ & $105,25 \mathrm{~d}$ & $56,27 \mathrm{~d}$ \\
\hline
\end{tabular}

Keterangan: Angka yang diikuti huruf yang sama berbeda nyata pada taraf 5\% 
Penurunan kehilangan hasil dan pertumbuhan cabai merah tidak saja menyebabkan penurunkan populasi aphid, tetapi juga penurunan intensitas gejala virus kuning. Penurunan intensitas virus lebih dari $50 \%$ diperoleh dari pemberian minyak serai $0,6 \%$ maupun nanopestisida $0,2 \%$ (Tabel 1). Hal ini disebabkan aphid merupakan vektor utama penularan pathogen virus pada pertanaman cabai merah.

Hasil pengamatan menunjukkan pertanaman cabai merah yang diaplikasikan minyak serai menghasilkan intensitas virus kuning yang lebih rendah (Tabel 1). Dengan demikian peningkatan pertumbuhan dan penurunan kehilangan hasil cabai merah pada pengendalian aphid dengan minyak serai tidak saja disebabkan penurunan populasi aphid per tanaman, namun juga penurunan intensitas virus kuning oleh penurunan populasi aphid sebagai vektor utama penularan virus kuning pada cabai merah.

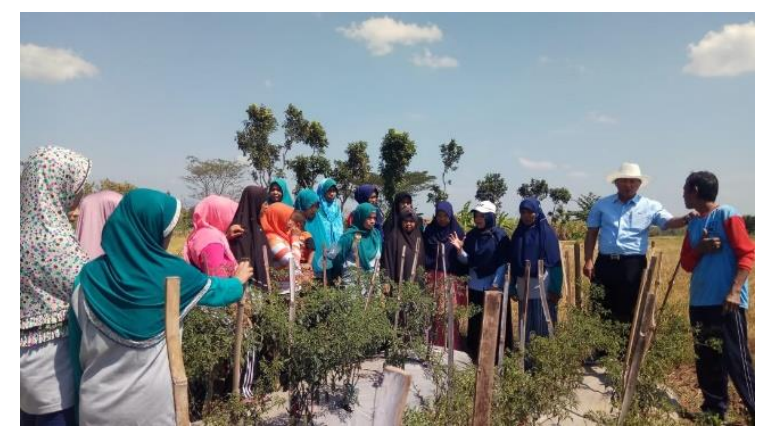

Gambar 3. Pelatihan aplikasi nanoteknologi biopestisida serai wangi

\section{Monitoring dan Evaluasi}

Pelatihan aplikasi nanoteknologi biopestisida di lahan cabai petani mitra juga menunjukkan hasil minyak serai yang diformulasikan dengan teknologi nanopestisida lebih efektif mengendalikan aphid dibandingkan minyak serai yang diaplikasikan secara langsung (Gambar 3). Menurut Bergeson (2016) teknologi nano dapat memperkecil partikel hingga berukuran nano $\left(10^{-9} \mathrm{~m}\right)$ sehingga menjadikan bahan aktif pestisida mudah diserap oleh serangga sasaran dan menjadikannya lebih efektif. Teknologi nano yang disertai dengan enkapsulasi akan menjadikan bahan aktif pestisida tidak lebih mudah menguap sehingga lebih stabil. Bouwmeester et al. (2009) menyampaikan nanoenkapsulasi dan nanoemulsi merupakan teknik nanopestisida yang sudah banyak digunakan dan efektif untuk pengendalian penyakit tanaman. Yanuar dan Widawati (2017) menambahkan pengembangan nanoteknologi pada pestisida baik itu pestisida kimia maupun pestisida organik akan dapat membantu meningkatkan efisiensi penggunaan insektisida. Lebih jauh lagi, penggunaan pestisida secara langsung pada target akan meminimalisir berkembangnya mekanisme resistensi pada hama dan mengurangi kematian serangga non target.

Penggunaan nanopestisida secara berkelanjutan oleh para petani saat ini memang masih sulit dilakukan karena produk nanoteknologi biopestisida belum dijual secara luas dan harganya cukup mahal. Oleh karena itu tim pengabdian juga menyampaikan metode ekstraksi sederhana dari serai wangi dan tanaman lain sehingga dapat digunakan sebagai biopestisida. Pembelian produk nanoteknologi biopestisida dapat dikelola dan digunakan secara bersama oleh kelompok tani sehingga lebih hemat. Terlebih lagi karena penggunaannya dalam konsentrasi yang sangat sedikit saat aplikasi penyemprotan maka produk nanoteknologi biopestisida dapat digunakan secara bersama dalam satu kelompok tani.

\section{KESIMPULAN}

Kegiatan pengabdian di Desa Cabeyan, Kecamatan Bendosari, Kabupaten Sukoharjo telah meningkatkan pengetahuan dan keterampilan mitra mengenai teknik budidaya tanaman cabai yang baik dan pengelolaan hama penyakit ramah lingkungan. Input utama yang diperoleh mitra yaitu penurunan intensitas penyakit lebih dari $50 \%$ dan penurunan kehilangan hasil hingga $79 \%$ pada tanaman cabai dengan nanoteknologi menggunakan ekstrak minyak serai wangi. Nanopestisida alami ini aman terhadap lingkungan, mudah diolah dan diaplikasikan sesuai dengan prinsip sistem pertanian berkelanjutan, serta efektif dan efisien dalam penggunaan sehingga dapat meningkatkan kesejahteraan petani mitra.

\section{UCAPAN TERIMAKASIH}

Penulis menyampaikan terima kasih kepada Ketua LPPM Universitas Sebelas Maret atas pemberian Dana Hibah PNBP TA 2019 dengan nomor 517/UN27.21/PM/2019 sehingga kegiatan pengabdian ini dapat terselenggara dan selesai dengan baik. 


\section{DAFTAR PUSTAKA}

Ariningsih E. 2016. Prospects of Nanotechnology Application in Agriculture and Food Processing in Indonesia. Forum Penelit Agro Ekon. 34(1):1-20.

Ariyanti NA. 2012. Mekanisme infeksi virus kuning cabai (pepper yellow leaf curl virus) dan pengaruhnya terhadap proses fisiologi tanaman cabai. In: Seminar Nasional IX Pendidikan Biologi. p. 682 686.

Budi Kurniasih. 2018. Serangan Virus Kuning pada Tanaman Cabai Bisa Dicegah Artikel ini telah tayang di Kompas.com dengan judul "Serangan Virus Kuning pada Tanaman Cabai Bisa Dicegah", https://ekonomi.kompas.com/read/2018/0 7/10/133200826/serangan-virus-kuningpada-tanaman-caba. Kompas Com. 10/07/2018.

Bergeson, L.L. 2016. Nanosilver: US EPA's Pesticide Office Considers How Best to Proceed. Environmental Quality Management. 19, 79-85. I

Bouwmeester, H., Dekkers, S., Noordam, M.Y., Hagens, W.I., Bulder, A.S., de Heer, C., ten Voorde, S.E.C.G., Wijnhoven, S.W.P., Marvin, H.J.P. \& Sips, A.J.A.M. 2009. Review of Health Safety Aspects of Nanotechnologies in Food Production. Regulatory Toxicology and Pharmacology. 53 (1) 52-62.

Duhan JS, Kumar R, Kumar N, Kaur P, Nehra K, Duhan S. 2017. Nanotechnology: The new perspective in precision agriculture. Biotechnol Reports. 15:11-23. doi:10.1016/j.btre.2017.03.002.

Ely Novrianty, Nasriati, Fauziah. 2013. Pengendalian Virus Kuning Tanaman Cabe.

Gaswanto R, Syukur M, Hidayat SH, Gunaeni N. 2016. Identifikasi Gejala dan Kisaran Inang Enam Isolat Begomovirus Cabai di Indonesia. J Hortik. 26(2):223-234.

Goodyer LI, Croft AM, Frances SP, Hill N, Moore SJ, Onyango SP, Debboun M. 2010. Expert review of the evidence base for arthropod bites avoidance. J Travel Med 17:1708-8305.

Gunaeni N, Wulandari AW. 2010. Cara Pengendalian Nonkimiawi terhadap Serangga Vektor Kutudaun dan Intensitas Serangan Penyakit Virus Mosaik pada
Tanaman Cabai Merah. J Hortik. 20(4):368-376.

Hartati, SR. 2012. Prospek pengembangan minyak atsiri sebagai pestisida nabati. Perspektif 11(1):37-43.

Isman MB. 2000. Plant essential oil for pest and disease management. Crop Protection 19:603-608.

Kwon Y, Kim SH, Ronderos DS, Lee Y, Akitake B, Woodward OM, Guggino WB, Smith DP, Montell C. 2010. Drosophila TRPA1 channel is required to avoid the naturally occurring insect repellent citronellal. Current Biology 20:1672-1678. DOI: 10.1016/j.cub.2010.08.016.

Manjunatha SB, Biradar DP, Aladakatti YR. 2016. Nanotechnology and its applications in agriculture: A review. J Farm Sci. 19(1):1-13.

Mutchler E. 1991. Dinamika Obat: Buku Ajar Farmakologi dan Toksikologi. Edisi 5. Diterjemahkan oleh Widianto M, Kanto AS. ITB. Bandung.

Noveriza R, Mariana M, Yuliani S. 2017. Keefektifan Formula Nanoemulsi Minyak Serai Wangi terhadap Potyvirus Penyebap Penyakit Mosaik pada Tanaman Nilam. Bul. Littro, 28 (1):47-56. DOI: http://dx.doi.org/10.21082/bullittro.v28n 1.2017.47-56

Setiawati W, Udiarto B, Soetiarso T. 2008. Pengaruh varietas dan sistem tanam cabai merah terhadap penekanan populasi hama kutu kebul. J Hortik. 18(1):55-61.

Shah MA, Wani SH, Khan AA. 2016. Nanotechnology and insecticidal formulations. J Food Bioeng Nanoprocessing. 1(3):285-310.

Vivaldy' LA, Max-M R, Guntur-S-J M. 2017. Insidensi Penyakit Virus pada Cabai (Capscum anuum) di Desa Kakaskasen II Kecamatan Tomohon Utara Kota Tomohon. COCOS. 1(6):1-9.

Worrall E, Hamid A, Mody K, Mitter N, Pappu H. 2018. Nanotechnology for Plant Disease Management. Agronomy. 8(12):285. doi:10.3390/agronomy8120285.

Yanuar F, Widawati M. 2017. Pemanfaatan Nanoteknologi dalam Pengembangan Pupuk aan Pestisida Organik . Materi Loka Penelitian dan Pengembangan Penyakit Bersumber Binatang Ciamis, Litbang Kesehatan 2014. file://C:/Users/ASUS/Downloads/draft- 
PEMANFAATANNANOTEKNOLOGI

DALAMPENGEMBANGANINDUSTRI

PESTISIDAORGANIK.pdf

Zhao X, Cui H, Wang Y, Sun C, Cui B, Zeng Z.

2018. Development Strategies and

Prospects of Nano-based Smart Pesticide

Formulation. J Agric Food Chem.

66(26):6504-6512.

doi:10.1021/acs.jafc.7b02004. 